IZA DP No. 7349

Earnings Differentials and Returns to Education in China, 1995-2008

Yuling Cui

Daehoon Nahm

Massimiliano Tani

April 2013 


\title{
Earnings Differentials and Returns to Education in China, 1995-2008
}

\author{
Yuling Cui \\ Macquarie University \\ Daehoon Nahm \\ Macquarie University \\ Massimiliano Tani \\ Macquarie University \\ and IZA
}
Discussion Paper No. 7349
April 2013

IZA
P.O. Box 7240
53072 Bonn
Germany

Phone: +49-228-3894-0

Fax: +49-228-3894-180

E-mail: iza@iza.org

\begin{abstract}
Any opinions expressed here are those of the author(s) and not those of IZA. Research published in this series may include views on policy, but the institute itself takes no institutional policy positions. The IZA research network is committed to the IZA Guiding Principles of Research Integrity.

The Institute for the Study of Labor (IZA) in Bonn is a local and virtual international research center and a place of communication between science, politics and business. IZA is an independent nonprofit organization supported by Deutsche Post Foundation. The center is associated with the University of Bonn and offers a stimulating research environment through its international network, workshops and conferences, data service, project support, research visits and doctoral program. IZA engages in (i) original and internationally competitive research in all fields of labor economics, (ii) development of policy concepts, and (iii) dissemination of research results and concepts to the interested public.
\end{abstract}

IZA Discussion Papers often represent preliminary work and are circulated to encourage discussion. Citation of such a paper should account for its provisional character. A revised version may be available directly from the author. 
IZA Discussion Paper No. 7349

April 2013

\section{ABSTRACT \\ Earnings Differentials and Returns to Education in China, 1995-2008}

This paper estimates the returns to education of rural-urban migrants during the period of transition of China's economy between 1995 and 2008. Using data from CHIP and RUMiC, we find that rural migrants' earning differentials with urban residents are substantial and mainly depend on the type of occupation, industry, and employers' ownership, rather than the level of education completed. Returns to formal schooling for migrants remained stable at approximately 3\% and 5\% throughout the period, and differences across quantiles are generally statistically insignificant. Increasing gaps in the return to schooling by gender have instead emerged. These results raise questions about the incentives to invest in human capital for rural migrants and for the governments funding education in emigration regions.

JEL Classification: $\quad$ C31, J24, J61, 015

Keywords: returns to education, rural migrants, quantile regression, ownership enterprises, China, returns to schooling

Corresponding author:

Massimiliano Tani

Department of Economics

Macquarie University

Sydney, NSW 2109

Australia

E-mail: max.tani@mq.edu.au 


\section{Introduction}

Earnings differentials between different categories of workers in urban China expanded rapidly in the late-1980s. Between 1988 and 2007 the variance of log earnings of urban workers increased from 0.27 to 0.48 , rising by 78\% (Meng et al. 2010). The increased dispersion of returns to education seems to account for a significant part of this outcome. Research shows that the average rate of returns to education for urban workers increased from 4\% in 1988 to about 10\% in 2001 (Park et al. 2008, Zhang et al. 2005). These changes have been noted by economists (e.g. Li \& Zhang 1998, Yang 2005, Meng et al. 2010, Xing 2011), who attribute them to China's labour market reform from a centrally planned system to a market-oriented economy. Workers are paid differently in the face of different wage distribution mechanisms across different types of ownerships. Non-state owned enterprises (non-SOEs) are market-oriented and operate performance-linked wage policies. In contrast, state-owned enterprises (SOEs) are characterised by a bureaucratic system of administering wages ${ }^{1}$ based on seniority ${ }^{2}$ rather than training and educational qualifications (Meng 2000).

The economic returns to education of rural migrants have instead only partly analysed (e.g. Zhao 1997b, Lu \& Song 2006, De Brauw \& Rozelle 2008), and predominantly so for the early years of China's economic transition. These analyses tend to reveal a substantial difference in the rewards of rural migrant workers vis-à-vis their urban counterparts. Yet, a thorough understanding on whether the emergence of a market-based economy has raised the returns to education for rural migrants is highly relevant to understand not only the working

\footnotetext{
${ }^{1}$ The wage distribution of SOEs was based on the Soviet model and remained in place until 1988. It was heavily depended on seniority and qualification rather than job performance, which curtailed economic efficiency (Meng 2000). Thus, the wage reform that decentralized wage-setting authority to individual enterprises and led wages become more market-determined and performance-linked was implemented after 1988. Employees' wages were changed to be composed of the basic wage, the functional wage relating to status and seniority, and the floating wage depending on an individual's productivity and an enterprise's profitability (Knight \& Song 2003).

${ }^{2}$ Seniority denotes the length of time that employees had been in any state workplace after 1949 or the period since the individual became a member of Chinese Communist Party (CCP).
} 
of China's cities' labour markets, but, most importantly, the underlying incentives for investing in education for rural migrants and policymakers of emigration regions.

This paper contributes to the existing literature by studying the returns to schooling of rural migrants over the past twenty years. In particular, it does so at three points of the wage distribution: the $10^{\text {th }}, 50^{\text {th }}$ and $90^{\text {th }}$ deciles. These three percentiles are normal practice in studies on income inequality (e.g. Xing 2011), and provide insights on the dynamics of prevailing wages across a broad spectrum of workers and skills. Our analysis is based on cross-sectional national data covering 1995, 2002 and 2008 from the China Household Income Project (CHIP), and the 2008 wave of a survey on Rural-Urban Migration in China (RUMiC). These datasets contain detailed information on demographic and socio-economic characteristics of migrants, as well as a broad geographical coverage.

We find no significant changes in returns to education for rural migrants over the period studied, with the average rates remaining in the range $3 \%-5 \%$. Wage increases are mostly explained by the job type, industry, and ownership structure of the employer rather than one's level of education. We also find a substantial increase in wage dispersion by gender negatively affecting rural migrant women. The fact that rural migrants do not appear to have benefited from a market-based system of reward for their human capital, unlike their urban counterparts, raises questions about the missing role of education in raising living standards. It also highlights the emergence of a dual labour market between an urban elite and a migrant underclass, as well as between male and female migrant workers.

The rest of the paper is organized as follows: Section 2 summarises relevant existing work. Section 3 presents data and the summary statistics. Section 4 discusses the methodology. Section 5 discusses the empirical results. Section 6 concludes. 


\section{Literature review}

The economic returns to education for urban workers in China have been well documented in existing literature, which shows that the average rate of returns and its growth were both slow at the early stage of the economic transition (1978-1988). ${ }^{3}$ The returns to education were only 1.5\% in 1978 (Li \& Zhang 1998), and this rate remained below 3.7\% in the 1980s (Byron \& Manaloto 1990, Meng \& Kidd 1997, Johnson \& Chow 1997). This phenomenon is likely associated with long-lasting institutional impacts of the egalitarian wage distribution system in China's former planned economy during that period. To maintain an equalized wage distribution, the measure of workers' seniority was introduced by the government to pro-up the returns low-skilled workers relative to well-educated workers (Filer et al. 1999).

With the progressing of a market-based economy after 1988, the returns to education among China’s urban workers began to increase significantly (Wu \& Xie 2003, Yang 2005, Li 2003, Zhao 2001, Maurer-Fazio 1999, Zhang et al. 2005). Using annual surveys of urban household conducted by China's National Bureau of Statistics (NBSC), Zhang et al. (2005) show that the average returns to education increased from 4\% in 1988 to $6.7 \%$ in 1995 before reaching 10.2\% in 2001. Using CHIP 1988 data, Liu (1998) finds that workers engaging in jobs that require high levels of education, like managerial and professional jobs, earn $17 \%$

\footnotetext{
${ }^{3}$ This kind of phenomenon presents a unique perspective of China compared to other transitional countries, for which returns to education grew rapidly after undergoing a similar economic transition towards a market-based production system. The returns to education typically rose following the initiation of reforms in Central and Eastern Europe (CEE) countries, but the speed was diverse across countries. Campos and Jolliffe (2003) find that returns to a year of schooling increased from $6.4 \%$ in 1986 to $11.2 \%$ in 1998 in Hungary. The estimated return to schooling increased by a third to 5.3\% between 1988 and 1992 as shown by Večerník (1995) in the Czech Republic; and then increased to 5.7\% in 1996 (Flanagan 1998). A similar evolution of returns to schooling occurred in Poland. Rutkowski (1996) shows that there was a dramatic rise in the wage premium for white-collar skills, and a significant jump in the returns to education in market-oriented reforms. To be specific, a 1987 return to schooling was 5\%, which was essentially the same as in the Czech Republic and Hungary. Then the returns increased to $7.9 \%$ in 1992 . The increased returns were mainly driven by the wage gains experienced by university-educated workers in the private sector. Returns to schooling appear to have increased during the transition in Russia as well. Brainerd (1998) finds that the transition to a market economy has produced a substantial and rapid change in the wage structure. The returns to education for women increased from $5.4 \%$ in 1991 to $9.6 \%$ in 1994, while the returns for men increased from 3.1\% to $6.7 \%$ during the same period.
} 
higher wages than those in jobs that require low levels of education, such as manual jobs. Aside from job-related return differentials, the earning dispersion also widened significantly in specific cities between 1988 and 1995 (Yang 2005, Whalley \& Xing 2010).

Against increased returns to schooling for urban workers during the 1980s and 1990s, existing research shows that education remained a poor investment for rural migrants during the same period: the rates of return to senior high school education was $8.3 \%$ in 1979 but these decreased to $4.3 \%$ in 1985 (Zhao 1997a). Significant wage differences across ownerships for rural migrants were also observed. ${ }^{4}$ As an example, the wages earned in jointventure enterprises was 41\% higher than those of SOEs surveyed in Tianjing in 2003 (Lu and Song, 2006). There is however little information on whether the continuing economic transition towards a market economy has widened the returns to education of China's rural migrants, supporting incentives to invest in human capital.

Widening wages across different levels of human capital is typically analysed with non-parametric techniques or considered at set points of the wage distribution. The literature highlights the heterogeneity of returns to education among individuals with varying levels of education and abilities (e.g. Heckman and Li, 2004; Wang et al., 2007; Koop and Tobias, 2004; Harmon et al., 2003). A common technique to estimate the returns to education at various points of the wage distribution is quintile regression. Unlike linear regression by Ordinary Least Squares (OLS), whose estimates only indicate the mean value of wages for given levels of years of schooling, quantile regression estimates the change in a specified quantile of the wage distribution produced by a one unit change in years of schooling. This allows one to better compare the effect of schooling on sub-groups of the working population, as the wage distribution generally reflects different levels of competences and skills. The

\footnotetext{
${ }^{4}$ By contrast, no significant return differentials across four types of enterprises (SOEs, township and village enterprises, joint venture, and foreign-invested firms) for rural migrants appear to exist, as found in the cases of Xiamen and Dalian cities, which were surveyed in 1998 (Dong \& Bowles 2002).
} 
results from quantile regression results can be therefore more informative than those obtained by OLS. We provide them both in the analysis which follows.

Amongst the very few studies using quintile regression to estimate the returns of education in China, Xing (2007) finds that the returns to education in SOEs tended to be egalitarian at different percentiles, ranging between $2.3 \%$ and $2.8 \%$ in 1997 , while equivalent returns in non-SOEs were higher at the upper levels of the distribution (for example, the rate in private enterprises was 9.4\%). This result matches the findings observed by Zhang and Xue (2008) in Shanghai, Zhejiang and Fujian.

However, existing studies generally suffer from limitations related to the data used, which tend to cover the 1990s rather than more recent years and often relate to single or a handful of cities. Existing work is also predominantly focused on urban workers rather than rural migrants.

\section{Data and summary statistics}

We study the returns to education of rural-urban migrants with three datasets: the 1995 and 2002 waves of China Household Income Project (CHIP), and the 2008 wave of a survey on Rural-Urban Migration in China (RUMiC). CHIP survey is conducted by the Institute of Economics, Chinese Academy of Social Sciences, with assistance from the Asian Development Bank and the Ford Foundation. It has advantages over other data source in that the samples were chosen from significantly larger samples drawn by the National Bureau of Statistics of China (NBSC). There are a total of 1,505 and 5,327 rural-urban migrant individuals in CHIP 1995 and 2002, respectively. The survey also covers a large scale of variables to reflect socioeconomic variables, demographic characteristics, migration history, and the family situation before leaving the home village. 
RUMiC 2008 is used to replace CHIP 2007 to estimate the returns to education (CHIP 2007 is not publicly available yet). The 2008 wave of RUMiC is a large-scale household survey conducted in China. It is initiated by a group of researchers at the Australian National University, the University of Queensland and the Beijing Normal University with support by the Institute for the Study of Labour (IZA). It includes a rural to urban migrant survey, a rural household survey, and an urban household survey. The analysis is mainly based on the sample of 8,446 migrants in the most popular migration destination cities/provinces.

The migrants in the CHIP 1995, 2002 and RUMiC 2008 data are sampled from different receiving provinces. However, we limit observations to only those migrants moving into the same provinces in the three datasets, namely: Henan, Jiangsu, Anhui, Sichuan and Guangdong provinces. As Beijing and Shanghai are surveyed in the CHIP and RUMiC data respectively, to represent large municipalities with provincial status, Beijing is used for the analysis on returns to education in 1995 and 2002, while Shanghai is used as an alternative to Beijing for the year of 2008.

Ownership types are classified into SOEs, urban collective-owned enterprises (UCEs), private enterprises, and joint-venture and other enterprises (JVs). Private enterprises are wholly owned non-SOEs, consisting of urban private enterprises, which hire more than seven employees each, urban self-employed enterprises, which hire fewer than seven employees each, and foreign enterprises. Other enterprises include Sino-foreign joint venture companies, which are shared by public and foreign capital, and other share-holding companies (e.g. Sino-foreign cooperative companies), which are owned jointly by Chinese entities (e.g. offering factory buildings and equipment) and foreign entities (e.g. providing technology). There are four occupation types in the dataset: professionals/skilled workers, ordinary staff, unskilled workers, and managers/other. These occupations are distributed in four industries: manufacturing, construction, social services (including wholesale/retail/food 
services (WRF)), and industries with low employment percentage (ILEP) ${ }^{5}$ and other.

We choose to analyse hourly wages rather than monthly wages because, as shown by previous studies ( $\mathrm{Li}$ 2003, Li \& Zax 2000, Chen et al. 2005), educational levels are negatively correlated with working hours. More formally educated individuals tend to work fewer hours on average, and accordingly the returns to education based on monthly wages may be underestimated. Li (2003) finds that the returns to schooling were $5 \%$ based on annual wages, which were lower 0.5 percentage point when using hourly wages. Furthermore, workers can get higher earnings in private enterprises, which also demand longer working hours. The hours worked in private enterprises are around 65 hours/week, which is 10 hours more than that of working in SOEs during the period (see Table A1 in the Appendix).

Table 1 provides summary statistics of rural migrants who are aged 16 and above in 1995, 2002 and 2008. There are personal and job characteristics including years of schooling, work experience, the percentage of migrants who work across ownerships, occupations, industries and regions. Table 1 shows that migrants' schooling increased from about 7 to 9 years during this period. Similarly, the work experience accumulated in the urban labour market increased from around 2 to 8 years.

Table 1 additionally shows the mean hourly earnings and their standard deviation. Hourly earnings increased from 1.8 in 1995 to 2.7 in 2002, then to 9.1 in 2008. The corresponding standard deviations increased from 2.7 to 25.9 implying increasing wage dispersion. The variance increased more on the upper half of wage distribution in the 20022008 period (from 3.4 to 14.3), as also found in previous studies (e.g. Xing 2011, Xing \& Li 2012).

\footnotetext{
${ }^{5}$ ILEP denote those in which the employment percentage of rural migrants is no more than 3\%. ILEP includes mineral; geological prospecting and irrigation administration; finance and insurance; real state; scientific research and professional services; health, education, culture, material supply, marketing, and public utilities; government agents, party organizations and social groups; transportation, storage, post office and communication; and electricity, gas, water production and supply. See details in Table A2 in the Appendix.
} 
Significant changes are shown in ownership accompanying the increase of wage level. More than 40\% rural migrants in 1995 were in private enterprises, and this percentage increased to approximately 83\% between 2002 and 2008. In contrast, the percentage of working in SOEs decreased. The job losses in SOEs are offset by continuously growing number of non-SOEs.

Changes in occupation and industry composition also provide additional details about China's changing job structure. Nearly half of migrants were unskilled workers, and the number of unskilled migrants increased from 39\% in 1995 to $61 \%$ in 2008 . We also find that the number of professionals/skilled workers increased, and that the proportion of those working as 'ordinary staff' decreased from 37\% to 5\% in support of Goos and Manning's (2007) hypothesis that technological progress reduces the relative demand in "middle” jobs involving routine tasks, but raises the relative demand in well-paid skilled jobs (e.g. professional and skilled jobs) and in low-paid unskilled jobs because technology cannot replace human labour in non-routine (highly skilled and manual) tasks (Autor et al. 2003).

As regards the industrial type, about 48\% migrants engage in manufacturing in 1995. Social service is the most important source of migrants’ employment in 2002 and 2008. The industrial transformation ${ }^{6}$ of China during this period may underpin this significant change.

\section{Methodology}

Following Mincer, we analyse the relationship between the logarithm of earnings and education. The variant used is:

$$
\ln y_{i}=\beta_{0}+\beta_{1} S_{i}+\beta_{2} E_{i}+\beta_{3} E_{i}^{2}+\beta_{4}^{\prime} Z_{i}+\varepsilon_{i}
$$

\footnotetext{
${ }^{6}$ According to the National Industries Classification (GB/T4754-2002) in 2002, the industries can be classified into primary industry, secondary industry, and tertiary industry. The primary industry includes agriculture, forestry, farming and fishing. The secondary industry contains mineral, manufacturing, construction, as well as electricity, gas and water production and supply. The rest are the tertiary industry. The industrial transformation denotes decreasing the proportion of the primary and secondary industries while increasing the proportion of the tertiary industry in the market economy. Its aim is to promote the quality and efficiency of economic growth in the context of deepening Chinese economic reform. See Ling and Deng (2004).
} 
where $y_{i}$ is the hourly earnings including wages, bonus, allowance and commutation in kind for wage earners. $S_{i}$ is years of schooling. $E_{i}$ is the work experience in the urban labour market. It denotes non-agricultural work experience in 1995 and city work experience in the years of 2002 and 2008. The quadratic term of experience $E_{i}^{2}$ is also included as its effect may not be linear as shown by previous studies (Yang 2005, Fleisher et al. 2005). $\varepsilon_{i}$ is an independently and normally distributed error term with variance $\sigma^{2}$. The vector $Z_{i}$ represents five other characteristics that probably affect earnings, including gender (male=1), ownership types (the reference group: private enterprises), occupational types (the reference group: unskilled workers), industry dummies (the reference group: social services), and the region. Guangdong is taken as the reference province because it is one of the largest and most rapidly changing cities in China's economy, and it experienced the highest immigration rate in the 2000s. Regional dummies are included to capture different spatial rates of economic activity. China's regions are significantly different in natural resources and in the pace of economic reforms (Falkenheim 1988, Fu \& Gabriel 2001).

In equation (1), the parameter $\beta_{1}$ measures the percentage change in wage for each additional year of schooling. We expect that workers with a higher education level will earn higher wages ceteris paribus. We also expect that work experience, as an element of human capital, relates positively to earnings. Non-SOEs, and especially JVs, are expected to offer higher earnings to employees on average due to their higher productivity.

Endogeneity might be a problem in the estimation because some unobservable factors, such as the capability and diligence of a migrant, might affect the logarithm of earnings as well as the years of schooling. If high-ability individuals are over-represented in higherschooling levels (because they face lower marginal costs to schooling, for instance), then not considering differences in ability would wrongly lead to over/underestimate the returns to 
education at the upper/lower part of the conditional wage distribution and measurement error. We use the sending region and health as the instrumental variables (IV) and apply the Hausman test for endogeneity. Although the sending region includes different numbers of provinces and municipalities, we assume that it follows the same selection framework: Beijing and Shanghai represent the municipalities; Liaoning, Hebei, Shandong, Zhejiang, Jiangsu, Fujian, Guangdong, Guangxi, and Hainan the coastal region; the rest the interior region. The dummy variable of the sending region consists of municipalities, the coastal region, and the reference interior region. The rationale is that migrants from municipalities and the coastal region are thought to have stronger capability than those from the interior region due to better teaching quality and facilities (Maurer-Fazio 1999). For the Hausman test, we firstly predict schooling by regressing it on the full set of the exogenous variables including health and the sending region. Then, the predicted schooling (denoted S-hat) is included in the Mincer equation and the significance of its coefficient is tested for the endogeneity of schooling. The results in Table 2 show that the $P$-values are $0.2952,0.1670$, and 0.1162 for 1995,2002 , and 2008, respectively. All the $p$-values are greater than 0.10 , implying that there is no significant evidence that schooling is endogenous. According to the results of weak IV tests reported in Table 3, sending region and health are strong instruments for schooling in general.

The usual mean regression summarizes the average relationship between the dependent variable and a set of independent variables, based on the conditional mean function. However, this approach only provides a partial view of the relationship. If there exists heterogeneity in the regression coefficients across different levels of earning, analyses based only on the conditional mean equation would be severely affected (Koenker \& Bassett 1978). Instead, a more complete relationship between the regressand and the regressors at 
different points in the conditional distribution can be analysed using the quantile regression (QR).

QR has considerable appeal for several reasons (e.g. Cameron and Trivedi, 2009). Firstly, it is more robust to outliers than the mean regression. To see why this is the case, let $e_{i}$ refers to the prediction error term. The quantile $q, q \in(0,1)$, is defined as the value of $y$ that splits the data into the proportions $q$ below and $1-q$ above. While the OLS estimator minimizes $\sum e_{i}^{2}$, QR minimizes a loss function that is the sum of the asymmetric losses $(1-q)\left|e_{i}\right|$ for overprediction and $q\left|e_{i}\right|$ for underprediction. Secondly, QR facilitates a more comprehensive understanding of the data as the effect of a covariate on the full distribution or any particular percentile of the distribution can be studied by QR. Thirdly, unlike OLS, QR estimators do not require the existence of the conditional mean for consistency. This feature is especially suitable when heteroscedasticity is present. Finally, QR is invariant to monotonic transformations. This means that the quantiles of a transformed variable $y$, denoted by $f(y)$, where $f(y)$ is a monotonic function, equal to the transforms of the quantiles of $y$, so $Q_{q}\{f(y)\}=f\left\{Q_{q}(y)\right\}$. Hence, if the quantile model is expressed as $\ln (y)$, then the inverse transformation can be used to translate the results back to $y$. This is not possible for the mean regression, because $E\{f(y)\} \neq f\{E(y)\}$ unless $\mathrm{f}($.$) is a linear function.$

The QR model can be written as:

$$
\ln y_{i}=x_{i}^{\prime} \beta_{q}+\mu_{q i} \quad \text { with } \quad Q_{q}\left(\ln y_{i} \mid x_{i}\right)=x_{i}^{\prime} \beta_{q}
$$

where $x_{i}$ is the vector of independent variables, the same as those in the OLS estimator, including years of schooling, potential work experience in the urban labour market, squared experience, gender, ownership types, occupational types, industry dummies, and regional factors. $\beta_{q}$ is the vector of parameters for the $q$-th qunatile. $Q u a n t_{q}(\ln y \mid x)$ denotes the $q$-th conditional quantile of $\ln y$ given $x$. The $q$-th regression quantile, $0<q<1$, is defined as a solution to the problem: 


$$
\min _{\beta \in R^{k}}\left\{\sum_{i: \ln y_{i} \geq x_{i}^{\prime} \beta}^{N} q\left|\ln y_{i}-x_{i}^{\prime} \beta_{q}\right|+\sum_{i: \ln y_{i}<x_{i}^{\prime} \beta}^{N}(1-q)\left|\ln y_{i}-x_{i}^{\prime} \beta_{q}\right|\right\}
$$

The least absolute deviation (LAD) estimator of $\beta$ is a specific case within this framework. This is obtained by setting $q=0.5$ (the median regression). By changing the value of $q$, any quantile of the conditional distribution can be obtained. The first quantile is obtained by setting $q=0.10$. Since the minimisation problem has no explicit form, linear programming techniques are used to solve the problem in equation (3). The standard errors of the estimates are obtained by the bootstrapping method, which provides robust results (Koenker \& Hallock 2001). The quantile regression coefficients measure the change in the $q$ th percentile (or quantile) of $\ln y_{i}$ caused by a one-unit increase in the independent variable. We expect that the schooling coefficient at the upper percentile of the estimate distribution is more than it is at the lower levels (e.g. the $10 \%$ percentile).

\section{Empirical Results}

Table 4 presents the average rates of schooling returns for rural migrants in the years of 1995, 2002, and 2008. Columns (1) to (3) give the estimates of the basic Mincerian specification relating to personal characteristics (i.e. schooling, work experience, and gender). Columns (4) to (9) are expanded versions shown in equation (1). All regressions are estimated by OLS with robust standard errors to correct for heteroscedasticity of an unknown form. Specifically, the three dimensions of job heterogeneity - ownership, occupation type, and industry, may lead to heteroscedastic errors. For all regressions, the high $F$-values reject the null hypotheses that all of the slope coefficients are jointly equal to zero.

As observed from all columns, the coefficients across different models (i.e. columns 1-3, 4-6, and 7-9) seem to be quite similar to one another. This similarity implies that the variables that are included in all the three models (i.e. schooling, work experience, squared 
experience and gender) are almost orthogonal to the variables added in the larger model (7-9). The average rates of return to schooling do not have a substantial change over this period, ranging between $3 \%$ and $5 \%$. This rate is similar to that of urban residents for the pre-1995 cohort, indicating that the schooling returns for rural migrants are around ten years behind those of urban residents. The relation of rural migrants' logarithmic hourly earnings to the potential market experience has a widely documented inverted U-shape, and the returns to experience have a decreasing tendency over time. This seems to indicate a weakening role of work experience in affecting earnings' attainment. Contrary to these trends, the gender earnings difference was nearly five times in percentage terms, rising from 4\% in 1995 to 23\% in 2002 and having a slight decrease in 2008 (21\%).

Although Table 1 shows that SOEs are the least likely to hire rural migrants in China, the wages offered are the highest among all ownerships in 1995, and this is consistent with the statistics in the columns (4) to (6) of Table 4. However, the coefficients suddenly turned negative in $2002(-0.13)$ and in 2008 (-0.01). A possible explanation is that wages in SOEs increased more slowly than those in the other types of employment, which has been shown broadly in previous literature (Meng \& Kidd 1997, Fan 2001). Additionally, the rapid development of private enterprises and the productivity-linked wages offered are probably an important reason of the relatively low payment in SOEs in comparison to private enterprises. The wage levels of JVs were significantly positive in all the three years implying a high marginal product of labour ( $\left.\mathrm{MP}_{\mathrm{L}}\right)$ attributable to a higher capital-intensity (Lee 1999).

The regression coefficients in columns (7) to (9) suggest that the managerial and communication skills associated with managers could play a significant role in earnings' attainment. Managers obtained the highest wage levels in 1995 and 2008. The corresponding payment received was around $30 \%$ and $42 \%$, respectively higher than that for unskilled 
workers. ${ }^{7}$ Despite the coefficient estimates of schooling returns for ordinary staff were statistically significant and positive in all the three years, the value decreased from 0.22 in 1995 to 0.08 in 2008.

The discrepancies in the wage levels across industries are closely related to the characteristics of industry and its labour market conditions. Migrants in ILEP industries earned significantly higher wages (35\%) in 1995 than other years, while high wages are paid in construction between 2002 and 2008. ILEP are mostly monopolistic industries, including electricity/gas/water production and supply, as well as finance and insurance, which could offer relatively higher wages than social services (the reference group) (Zhang 2004). The high earnings obtained in construction may be due to the boom and speculation characterising the real estate market in those years. The significant differences in the coefficients for the industry dummies may help explain the average earnings differentials for rural migrants.

Wage heterogeneity is also reflected across regions. Migrants on average obtain higher wages in municipalities and coastal regions than interior regions. Among all provinces, the wages received in Jiangsu was the highest in 1995 before transferring to Guangdong in 2002. In 2008, Beijing offered on average higher wages than Guangdong.

The OLS results suggest that the returns to schooling for rural migrants were low and did not vary significantly between 1995 and 2008. This contrasts with the rising returns enjoyed by urban residents. Ownership, occupation, industry, and regions appear to explain this increasing earnings’ gap.

\footnotetext{
${ }^{7}$ When the dependent variable is the logarithm of earnings, the coefficient for an explanatory variable usually represents a percentage change in earnings caused by a unit increase in the explanatory variable. This is approximately the case only if a unit change in the explanatory variable is marginal (i.e., small relative to the average level of the variable). If the explanatory variable is a dummy variable, for example, the increase in the dummy can only be from 0 to 1 , which is discrete and not marginal. In such cases, the interpretation of the coefficient is as follows. If the coefficient for a dummy variable is $\delta$, the percentage difference in the average earnings between the two groups (i.e. the group with $D=0$ and the group with $D=1$ ) is more accurately calculated by $100 \times\left(\mathrm{e}^{\delta}-1\right) \%$.
} 
Table 5 reports the quantile regression estimates at the $10^{\text {th }}, 50^{\text {th }}$, and $90^{\text {th }}$ percentiles. The results show that the estimated coefficients for the characteristics are generally different at different quantiles, indicating that returns to schooling and jobs were heterogeneous on the conditional distribution of earnings, and the pattern changed between 1995 and 2008.

We find that the quantile regression provides a more complete description of wage determination than OLS regression. For example, from the OLS regression, the return to one more year of schooling is around $4 \%$ for rural migrants during this period. According to the QR regression, however, returns to schooling were higher at upper-level positions in the conditional distribution in 2002 and 2008. The returns to schooling ranged from 5\% to 6\% at the $90^{\text {th }}$ percentile, while they were 3\% at lower percentiles in the 2002 and 2008 cohorts. The $4 \%$ rate of schooling returns estimated from the OLS regression apparently conceals the heterogeneity in returns to schooling at different points of wage distribution, though the heterogeneity is small. Furthermore, the differences in the schooling return appear insignificant between the upper and lower levels, suggesting that higher education does not play an important role in earnings' increases. These are likely to reduce migrants' incentives to invest in education.

The wage differentials of ownership between the upper and lower quantiles are also small. The returns to education are found to be higher in SOEs as opposed to private enterprises in 1995. The coefficient for SOEs workers was 0.33 in the $10^{\text {th }}$ percentile and 0.51 in the $90^{\text {th }}$ percentile. In 2002, the coefficients turned negative and insignificant at the $10^{\text {th }}$ and $50^{\text {th }}$ percentiles. Workers received the lowest earnings among the ownership types, and this is most prominent in the $90^{\text {th }}$ percentile $(-0.24)$. In 2008 , the coefficients for SOEs are positive but insignificant in the all three percentiles. The above results indicate that the low returns for rural migrants are a characteristic of wage distribution in SOEs: it mainly appears 
for those highly educated at upper percentiles of earnings in 2002, while the dispersion in schooling returns converged somewhat in 2008.

Quantile regressions at various percentiles also give a more detailed description of the conditional distribution of wages across occupations. The effects of being a professional or a manager on earnings are generally higher in upper quantiles than those in lower levels, indicating large earnings differentials within each occupation. Over time, managerial jobs have become more valuable, as shown by widening wage dispersion relative to other occupations. Professionals in various percentiles earned more than unskilled workers in 1995 and 2002. At the $90^{\text {th }}$ percentile, the value of schooling coefficients for professionals was $41 \%$ in 1995 and 36\% in 2002. Occupations explain an increasing and significant part of migrants’ earnings, unlike the level of formal education.

The gender return gap also becomes more prevalent in the years of 2002 and 2008: the coefficients for male workers are all positive and statistically significant in all three percentiles whereas only the median rate of schooling returns for males was significant (in 1995). Education appears to become a more important factor underpinning rural migrants' gender wage inequality. The results furthermore show that the wage differentials by gender at the bottom part of the wage distribution have become wider over time, as the returns increased from 0.14 (1995 and 2002) to 0.22 (2008). Female migrants with lower education bear the highest disadvantage in earnings’ attainment.

\section{Concluding remarks}

The low and stable returns to education for rural migrants are inconsistent with the rising returns enjoyed by urban residents during the same period of economic transition from a central, socialist system to a market-based economy. Three possible explanations may account for this result. 
First, returns to over-education are lower than the returns to "appropriate" education at lower levels of wage distribution. Most rural migrants appear to take jobs with low-skill physical jobs in construction and manufacturing. Highly educated workers employed in lowskilled jobs may experience low returns to education. Nearly $34 \%$ of rural migrants had senior middle and higher levels of formal education, but only $0.8 \%$ of them received college and above levels in 2004 (Wei \& Han 2006).

Second, differences in the educational quality may be another driving force for the patterns uncovered (e.g. Martins and Pereira, 2004). The Mincer equation considers only personal educational levels and not the quality of education. Migrants with low returns to education may be those who experienced poor school quality or have chosen fields of study with poor returns, even if they have high educational levels.

Third, technology progress and pressure from additional migration could have played an increasing part in determining demand for high-skill/high-quality migrant workers. Migrants’ work may be easily substituted by machines or competing new immigrants.

In any case, the low and relatively constant returns to schooling amongst rural immigrants raise queries for policymakers entrusted with improving migrants' continual education (jixu jiaoyu), which is viewed by Chinese authorities as an important factor for enhancing migrants' competitiveness in jobs requiring higher skills and training, and to improve individual productivity.

Aside from the low schooling returns, we also find significant widening wage gaps between male and female immigrant workers, especially in later years (2002 and 2008). Summary statistics show that the schooling differences between male and female migrants are less than 1 year. Thus, increasing wage gaps suggest that female migrants suffer from the 
double disadvantages of gender and holding a rural Hukou. This issue will become even more relevant as female migrants become a more prominent source of labour for urban China. 


\section{Reference}

Autor, D. H., Levy, F. \& Murnane, R. J. (2003) The skill content of recent technological change: An empirical exploration. The Quarterly Journal of Economics, 118, 1279-1333.

Brainerd, E. (1998) Winners and losers in Russia's economic transition. The American Economic Review, 88, 1094-1116.

Byron, R. P. \& Manaloto, E. Q. (1990) Returns to education in China. Economic Development and Cultural Change, 38, 783-796.

Cameron, A. C. \& Trivedi, P. K. (2009) Microeconometrics using Stata, Stata Press.

Campos, N. F. \& Jolliffe, D. (2003) After, before and during: returns to education in Hungary (1986-1998). Economic Systems, 27, 377-390.

Chen, Y., Démurger, S. \& Fournier, M. (2005) Earnings differentials and ownership structure in Chinese enterprises. Economic Development and Cultural Change, 53, 933-958.

De Brauw, A. \& Rozelle, S. (2008) Reconciling the returns to education in off-farm wage employment in rural China. Review of Development Economics, 12, 57-71.

Dong, X.-Y. \& Bowles, P. (2002) Segmentation and discrimination in China's emerging industrial labour market. China Economic Review, 13, 170-196.

Falkenheim, V. (1988) The political economy of regional reform: An overview. PP. 285-309. In Reynolds, B. L. \& Kim, I. J. (Eds.) Chinese economic policy: Economic reform at midstream. New York: Paragon House.

Fan, C. C. (2001) Migration and labour-market returns in urban China: Results from a recent survey in Guangzhou. Environment and Planning A, 33, 479-508.

Filer, R. K., Jurajda, Š. \& Plánovský, J. (1999) Education and wages in the Czech and Slovak Republics during transition. Labour Economics, 6, 581-593.

Flanagan, R. J. (1998) Were communists good human capitalists? The case of the Czech Republic. Labour Economics, 5, 295-312.

Fleisher, B. M., Sabirianova, K. \& Wang, X. (2005) Returns to skills and the speed of reforms: Evidence from Central and Eastern Europe, China, and Russia. Journal of Comparative Economics, 33, 351-370.

Fu, Y. \& Gabriel, S. A. (2001) Transitions to private employment: earnings determination, worker employment preferences, and job turnover in urban China. University of Southern California, Marshall School of Business Working Paper. http://papers.ssrn.com.

Giacobbe-Miller, J. K., Miller, D. J., Zhang, W. \& Victorov, V. I. (2003) Country and organizational-level adaptation to foreign workplace ideologies: A comparative study of distributive justice values in China, Russia and the United States. Journal of International Business Studies, 34, 389-406.

Goos, M. \& Manning, A. (2007) Lousy and lovely jobs: The rising polarization of work in Britain. Review of Economics and Statistics, 89, 118-133.

Harmon, C., Hogan, V. \& Walker, I. (2003) Dispersion in the economic return to schooling. Labour Economics, 10, 205-214.

Heckman, J. J. \& Li, X. (2004) Selection bias, comparative advantage and heterogeneous returns to education: Evidence from China in 2000. Pacific Economic Review, 9, 155-171. 
Huang, Z. \& Xu, K. (2006) Education of migrant workers and their children and its solutions. Journal of Zhejiang University (Humanities and Social Sciences), 36, 108-114 (in Chinese).

Johnson, E. N. \& Chow, G. C. (1997) Rates of Return to Schooling in China. Pacific Economic Review, 2, 101113.

Knight, J. \& Song, L. (2003) Increasing urban wage inequality in China Extent, elements and evaluation. Economics of Transition, 11, 597-619.

Koenker, R. \& Bassett, G., Jr. (1978) Regression quantiles. Econometrica, 46, 33-50.

Koenker, R. \& Hallock, K. F. (2001) Quantile regression. Journal of Economic Perspectives, 15, 143-156.

Koop, G. \& Tobias, J. L. (2004) Learning about heterogeneity in returns to schooling. Journal of Applied Econometrics, 19, 827-849.

Lee, Y. (1999) Wages and employment in China's SOEs, 1980-1994: Corporatization, market development, and insider forces. Journal of Comparative Economics, 27, 702-729.

Li, H. (2003) Economic transition and returns to education in China. Economics of Education Review, 22, 317328.

Li, H. \& Zax, J. (2000) Economic transition and labour supply in China. IN Wang, Y. \& Chen, A. (Eds.) China's labour market and problems of employment. (pp. 217-233), Southwest: University of Economics and Finance Press. http://www.prism.gatech.edu/ hl45/research/lbmkt.pdf.

Li, S. (1997) The model of labour migration in the Chinese transitional economy. Economic Research Journal, 1, 23-30 (in Chinese).

Li, T. \& Zhang, J. (1998) Returns to education under collective and household farming in China. Journal of Development Economics, 56, 307-335.

Ling, W. \& Deng, W. (2004) Industrial transition and economic growth in China. China Industrial Economy, 20-24 (in Chinese).

Liu, Z. (1998) Earnings, education, and economic reforms in urban China. Economic Development and Cultural Change, 46, 697-725.

Lu, Z. \& Song, S. (2006) Rural-urban migration and wage determination: The case of Tianjin, China. China Economic Review, 17, 337-345.

Martins, P. S. \& Pereira, P. T. (2004) Does education reduce wage inequality? Quantile regression evidence from 16 countries. Labour Economics, 11, 355-371.

Maurer-Fazio, M. (1999) Earnings and education in China's transition to a market economy Survey evidence from 1989 and 1992. China Economic Review, 10, 17-40.

Meng, X. (2000) Labour market reform in China, Cambridge University Press.

Meng, X. \& Kidd, M. P. (1997) Labour market reform and the changing structure of wage determination in China's state sector during the 1980s. Journal of Comparative Economics, 25, 403-421.

Meng, X., Shen, K. \& Xue, S. (2010) Economic reform, education expansion, and earnings inequality for urban males in China, 1988-2007. IZA Discussion Paper No. 4919. Bonn.

Park, A., Song, X., Zhang, J. \& Zhao, Y. (2008) Rising returns to skill, labour market transition, and the growth of wage inequality in China. working paper. 
Psacharopoulos, G. (1994) Returns to investment in education: A global update. World Development, 22, 13251343.

Rutkowski, J. (1996) High skills pay off: The changing wage structure during economic transition in Poland. Economics of Transition, 4, 89-112.

Schultz, T. W. (1975) The value of the ability to deal with disequilibria. Journal of Economic Literature, 13, 827-846.

Večerník, J. (1995) Changing earnings distribution in the Czech republic: Survey evidence from 1988-1994. Economics of Transition, 3, 355-371.

Wang, X., Fleisher, B. M., Li, H. \& Li, S. (2007) Access to higher education and inequality: The Chinese experiment. IZA Discussion Paper No. 2823. Bonn.

Wei, L. \& Han, C. (2006) The research report of rural migrant workers in China, Presented by Project Team of Research Office of the State Council, Beijing, Chinese Yanshi Press (in Chinese).

Whalley, J. \& Xing, C. (2010) The Regional Distribution of Skill Premia in Urban China. NBER Working Paper 16575. http://www.nber.org/papers/w16575.

Wu, X. \& Xie, Y. (2003) Does the market pay off? Earnings returns to education in urban China. American Sociological Review, 68, 425-442.

Xie, J. (2007) Measures on rural migrants' educational issues in the urbanization process. Education and Occupation, 18, 5-7 (in Chinese).

Xing, C. (2007) Wage determination and returns to education in different ownerships of China: Evidence from quantile regressions. Frontiers of Economics in China, 2, 114-136.

Xing, C. (2008) Human capital and wage determination in different ownerships, 1989-97. In Guanghua, W. (Ed.) Understanding inequality and poverty in China: methods and applications. Palgrave Macmillan.

Xing, C. (2011) Changes in job structure and rising wage inequality in urban China, 1995-2007. IZA Discussion Paper No. 6184. Bonn.

Xing, C. \& Li, S. (2012) Residual wage inequality in urban China, 1995-2007. China Economic Review, 23, 205-222.

Yang, D. T. (2005) Determinants of schooling returns during transition: Evidence from Chinese cities. Journal of Comparative Economics, 33, 244-264.

Zhang, J. \& Xue, X. (2008) Wage differentials and human capital contribution between state and non-state sector Journal of Economic Research, 04, 17-27 (in Chinese).

Zhang, J., Zhao, Y., Park, A. \& Song, X. (2005) Economic returns to schooling in urban China, 1988 to 2001. Journal of Comparative Economics, 33, 730-752.

Zhang, Z. (2004) Sectoral segmentation of labour markets and labour mobility. Population Science of China, 2, 45-52 (in Chinese).

Zhao, Y. (1997a) Labour migration and returns to rural education in China. American Journal of Agricultural Economics, 79, 1278-1287.

Zhao, Y. (1997b) Rural labour migration and the role of education. Economic Research, 2, 37-42 (in Chinese).

Zhao, Y. (2001) Foreign direct investment and relative wages: The case of China. China Economic Review, 12, 40-57. 


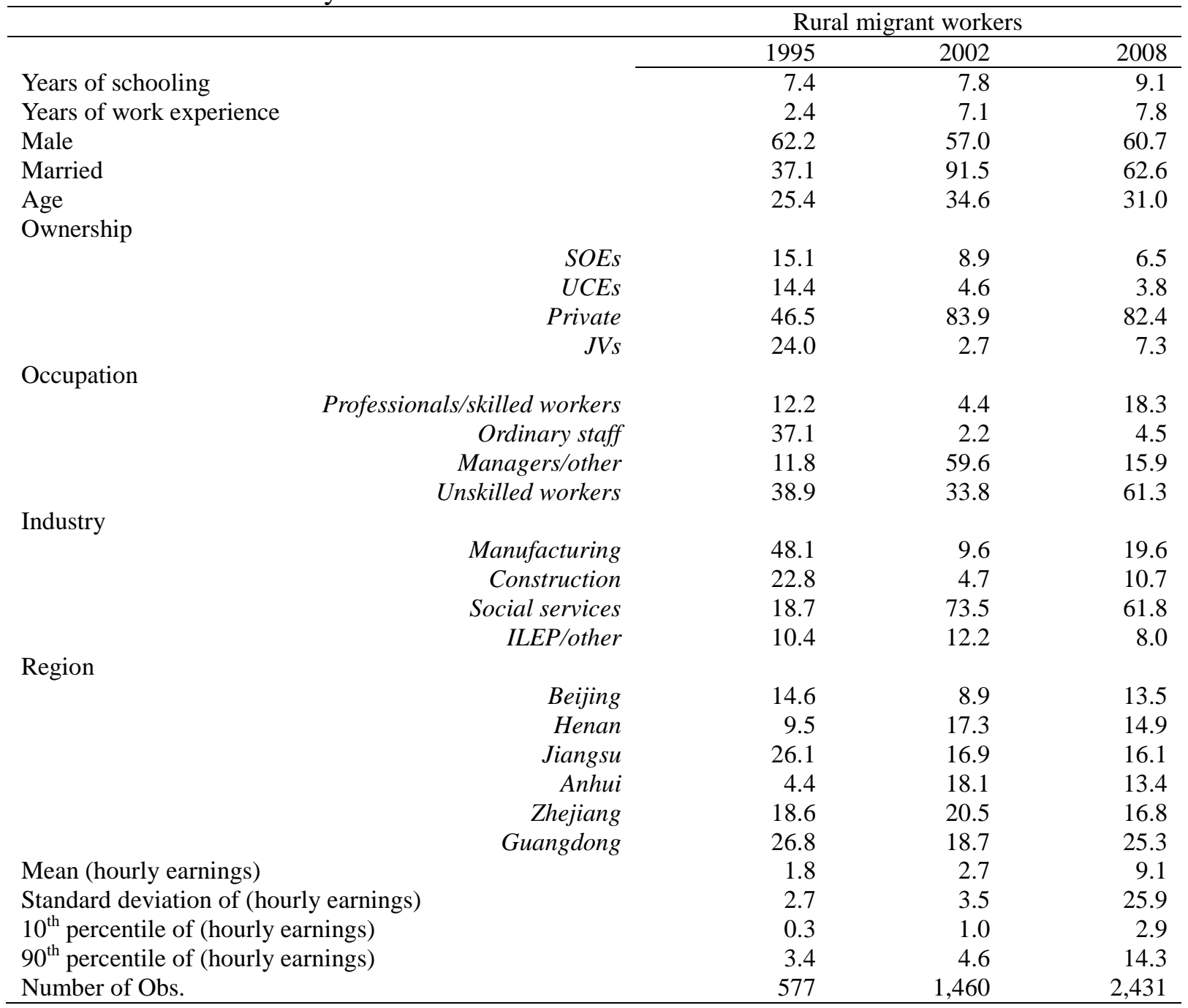

Table 2. F test for endogeneity

\begin{tabular}{l|l}
\hline \multirow{2}{*}{1995} & $\begin{array}{l}\text { Ho: the coefficient of yhat }=0 \\
\mathrm{~F}(1,422)=1.10, \text { Prob }>\mathrm{F}=0.2952\end{array}$ \\
\hline \multirow{2}{*}{2002} & $\begin{array}{l}\text { Ho: the coefficient of yhat }=0 \\
\mathrm{~F}(1,1346)=1.91, \text { Prob }>\mathrm{F}=0.1670\end{array}$ \\
\hline \multirow{2}{*}{2008} & $\begin{array}{l}\text { Ho: the coefficient of yhat }=0 \\
\mathrm{~F}(1,267)=2.48, \text { Prob }>\mathrm{F}=0.1162\end{array}$ \\
\hline
\end{tabular}

Table 3. Weak IV test

\begin{tabular}{c|l}
\hline \multirow{2}{*}{1995} & $\begin{array}{l}\text { Ho: The coefficients of sending provinces and health in IV are equal to zero. } \\
\mathrm{F}(3,421)=6.13, \text { Prob }>\mathrm{F}=0.0004\end{array}$ \\
\hline \multirow{2}{*}{2002} & $\begin{array}{l}\text { Ho: The coefficients of sending provinces and health in IV are equal to zero. } \\
\mathrm{F}(3,1358)=6.47, \text { Prob }>\mathrm{F}=0.0002\end{array}$ \\
\hline \multirow{2}{*}{2008} & $\begin{array}{l}\text { Ho: The coefficients of sending provinces and health in IV are equal to zero. } \\
\mathrm{F}(3,496)=2.12, \text { Prob }>\mathrm{F}=0.0971\end{array}$ \\
\hline
\end{tabular}


Table 4. Returns to schooling in 1995, 2002 and 2008, OLS

\begin{tabular}{|c|c|c|c|c|c|c|c|c|c|}
\hline & 1995 & 2002 & 2008 & 1995 & 2002 & 2008 & 1995 & 2002 & 2008 \\
\hline & (1) & (2) & (3) & (4) & (5) & (6) & (7) & (8) & (9) \\
\hline Schooling & $\begin{array}{l}0.03 * * * \\
(0.01)\end{array}$ & $\begin{array}{l}0.05^{* * * *} \\
(0.00)\end{array}$ & $\begin{array}{l}0.04 * * * \\
(0.01)\end{array}$ & $\begin{array}{l}0.02 * * \\
(0.01)\end{array}$ & $\begin{array}{l}0.05^{* * * *} \\
(0.00)\end{array}$ & $\begin{array}{l}0.04 * * * \\
(0.01)\end{array}$ & $\begin{array}{l}0.04^{* *} \\
(0.02)\end{array}$ & $\begin{array}{l}0.05 * * * \\
(0.01)\end{array}$ & $\begin{array}{l}0.04 * * * \\
(0.01)\end{array}$ \\
\hline Work experience & $\begin{array}{l}0.08 * * * \\
(0.01)\end{array}$ & $\begin{array}{l}0.05 * * * \\
(0.01)\end{array}$ & $\begin{array}{l}0.03 * * * \\
(0.01)\end{array}$ & $\begin{array}{l}0.06 * * * \\
(0.01)\end{array}$ & $\begin{array}{l}0.05 * * * \\
(0.01)\end{array}$ & $\begin{array}{l}0.04 * * * \\
(0.01)\end{array}$ & $\begin{array}{l}0.03 * * \\
(0.02)\end{array}$ & $\begin{array}{l}0.05 * * * \\
(0.01)\end{array}$ & $\begin{array}{l}0.03 * * * \\
(0.01)\end{array}$ \\
\hline Experience^2 & $\begin{array}{l}-0.002 * * * \\
(0.3 e-3)\end{array}$ & $\begin{array}{l}-0.001^{* * *} \\
(0.2 \mathrm{e}-3)\end{array}$ & $\begin{array}{l}-0.001^{* * *} \\
(0.2 \mathrm{e}-3)\end{array}$ & $\begin{array}{l}-0.001^{* * *} \\
(0.4 \mathrm{e}-3)\end{array}$ & $\begin{array}{l}-0.002^{* * *} \\
(0.3 \mathrm{e}-3)\end{array}$ & $\begin{array}{l}-0.001^{* * *} \\
(0.2 \mathrm{e}-3)\end{array}$ & $\begin{array}{l}-0.001^{* *} \\
(0.5 \mathrm{e}-3)\end{array}$ & $\begin{array}{l}-0.001^{* * *} \\
(0.4 \mathrm{e}-3)\end{array}$ & $\begin{array}{l}-0.001^{* * * *} \\
(0.2 \mathrm{e}-3)\end{array}$ \\
\hline \multicolumn{10}{|l|}{ Ownership } \\
\hline SOES & & & & $\begin{array}{l}0.33 * * * \\
(0.08)\end{array}$ & $\begin{array}{l}-0.13^{* * * *} \\
(0.04)\end{array}$ & $\begin{array}{l}-0.01 \\
(0.05)\end{array}$ & $\begin{array}{l}0.48 * * * \\
(0.12)\end{array}$ & $\begin{array}{l}-0.10 * * \\
(0.06)\end{array}$ & $\begin{array}{l}0.01 \\
(0.05)\end{array}$ \\
\hline UCES & & & & $\begin{array}{l}0.12 \\
(0.09)\end{array}$ & $\begin{array}{l}0.01 \\
(0.04)\end{array}$ & $\begin{array}{l}0.11 \\
(0.07)\end{array}$ & $\begin{array}{l}0.29 * * * \\
(0.10)\end{array}$ & $\begin{array}{l}0.01 \\
(0.05)\end{array}$ & $\begin{array}{l}0.16^{* *} \\
(0.07)\end{array}$ \\
\hline$J V s$ & & & & $\begin{array}{l}0.11 \\
(0.09)\end{array}$ & $\begin{array}{l}0.12^{* *} \\
(0.06)\end{array}$ & $\begin{array}{l}0.10 * * \\
(0.04)\end{array}$ & $\begin{array}{l}0.22 * * \\
(0.11)\end{array}$ & $\begin{array}{l}0.15^{* *} \\
(0.07)\end{array}$ & $\begin{array}{l}0.12 * * \\
(0.05)\end{array}$ \\
\hline \multicolumn{10}{|l|}{ Occupation } \\
\hline Professionals & & & & & & & $\begin{array}{l}0.10 \\
(0.14)\end{array}$ & $\begin{array}{l}0.15^{* *} \\
(0.07)\end{array}$ & $\begin{array}{l}-0.06 \\
(0.04)\end{array}$ \\
\hline Ordinary staff & & & & & & & $\begin{array}{l}0.22 * * \\
(0.09)\end{array}$ & $\begin{array}{l}0.21 * * \\
(0.10)\end{array}$ & $\begin{array}{l}0.08 \\
(0.05)\end{array}$ \\
\hline Managers/other & & & & & & & $\begin{array}{l}0.26 * * \\
(0.12)\end{array}$ & $\begin{array}{l}0.15^{* * * *} \\
(0.04)\end{array}$ & $\begin{array}{l}0.35 * * * \\
(0.05)\end{array}$ \\
\hline \multicolumn{10}{|l|}{ Industry } \\
\hline Manufacturing & & & & & & & $\begin{array}{l}0.16 \\
(0.10)\end{array}$ & $\begin{array}{l}0.15^{* * * *} \\
(0.05)\end{array}$ & $\begin{array}{l}0.01 \\
(0.03)\end{array}$ \\
\hline Construction & & & & & & & $\begin{array}{l}0.04 \\
(0.14)\end{array}$ & $\begin{array}{l}0.40 * * * \\
(0.08)\end{array}$ & $\begin{array}{l}0.18 * * * \\
(0.04)\end{array}$ \\
\hline ILEP/other & & & & & & & $\begin{array}{l}0.30 * * \\
(0.13)\end{array}$ & $\begin{array}{l}0.19 * * * \\
(0.06)\end{array}$ & $\begin{array}{l}0.10 * * \\
(0.05)\end{array}$ \\
\hline \multicolumn{10}{|c|}{ Receiving provinces } \\
\hline Henan & & & & & & & $\begin{array}{l}-0.26 * * \\
(0.11)\end{array}$ & $\begin{array}{l}-0.33 * * * \\
(0.05)\end{array}$ & $\begin{array}{l}-0.45^{* * *} \\
(0.04)\end{array}$ \\
\hline Jiangsu & & & & & & & $\begin{array}{l}0.26 * * \\
(0.11)\end{array}$ & $\begin{array}{l}-0.13^{* *} \\
(0.05)\end{array}$ & $\begin{array}{l}-0.01 \\
(0.04)\end{array}$ \\
\hline Anhui & & & & & & & $\begin{array}{l}-0.37 \\
(0.24)\end{array}$ & $\begin{array}{l}-0.33^{* * * *} \\
(0.05)\end{array}$ & $\begin{array}{l}-0.25^{* * *} \\
(0.04)\end{array}$ \\
\hline Sichuan & & & & & & & $\begin{array}{l}0.01 \\
(0.14)\end{array}$ & $\begin{array}{l}-0.43^{* * *} \\
(0.05)\end{array}$ & $\begin{array}{l}-0.30 * * * \\
(0.04)\end{array}$ \\
\hline Constant & $\begin{array}{l}-0.30 * * * \\
(0.07)\end{array}$ & $\begin{array}{l}-0.02 \\
(0.04)\end{array}$ & $\begin{array}{l}1.14^{* * * *} \\
(0.06)\end{array}$ & $\begin{array}{l}-0.30 * * * \\
(0.10)\end{array}$ & $\begin{array}{l}-0.01 \\
(0.04)\end{array}$ & $\begin{array}{l}1.11^{* * *} \\
(0.06)\end{array}$ & $\begin{array}{l}-0.68 * * * \\
(0.15)\end{array}$ & $\begin{array}{l}0.19 * * * \\
(0.07)\end{array}$ & $\begin{array}{l}1.16^{* * * *} \\
(0.07)\end{array}$ \\
\hline R-squared & 0.06 & 0.11 & 0.04 & 0.06 & 0.12 & 0.05 & 0.16 & 0.23 & 0.15 \\
\hline F-statictics & 32.41 & 109.68 & 40.68 & 12.76 & 55.23 & 26.94 & 6.35 & 27.39 & 24.08 \\
\hline Observations & 577 & 1,460 & 2,431 & 577 & 1,460 & 2,431 & 577 & 1,460 & 2,431 \\
\hline
\end{tabular}

Notes: Robust standard errors are in parenthesis. ${ }^{*} \mathrm{p}<0.1 ; * * \mathrm{p}<0.05 ; * * * \mathrm{p}<0.01$. Reference group of ownership types, occupation, industry, and receiving regions is private enterprises, unskilled workers, wholesale/retail/food services, and Guangdong, respectively. 
Table 5. Quantile regression results of returns to schooling in 1995, 2002, and 2008

\begin{tabular}{|c|c|c|c|c|c|c|c|c|c|}
\hline & \multicolumn{3}{|l|}{1995} & \multicolumn{3}{|l|}{2002} & \multicolumn{3}{|l|}{2008} \\
\hline & $10^{\text {th }}$ & $50^{\text {th }}$ & $90^{\text {th }}$ & $10^{\text {th }}$ & $50^{\text {th }}$ & $90^{\text {th }}$ & $10^{\text {th }}$ & $50^{\text {th }}$ & $90^{\text {th }}$ \\
\hline \multirow{2}{*}{ Schooling } & $0.06^{* *}$ & $0.02 * *$ & 0.01 & $0.03^{* * *}$ & $0.04 * * *$ & $0.05 * * *$ & $0.03 * * *$ & $0.06 * * *$ & $0.06 * * *$ \\
\hline & $(0.02)$ & $(0.01)$ & $(0.02)$ & $(0.01)$ & $(0.01)$ & $(0.01)$ & $(0.01)$ & $(0.01)$ & $(0.01)$ \\
\hline \multirow[t]{2}{*}{ Work experience } & $0.07 * * *$ & $0.06 * * *$ & 0.02 & $0.05^{* *}$ & $0.05^{* *}$ & $0.06^{* *}$ & $0.03^{* * *}$ & $0.04 * * *$ & $0.05^{* *}$ \\
\hline & $(0.03)$ & $(0.01)$ & $(0.02)$ & $(0.01)$ & $(0.01)$ & $(0.02)$ & $(0.01)$ & $(0.01)$ & $(0.02)$ \\
\hline \multirow[t]{2}{*}{ Experience ${ }^{\wedge 2}$} & $-0.001 *$ & $-0.002 * * *$ & $-0.3 e-3$ & -0.001 & $-0.001 * * *$ & -0.001 & $-0.001 * * *$ & $-0.001 * * *$ & $-0.001 * *$ \\
\hline & $(0.8 \mathrm{e}-3)$ & $(0.3 e-3)$ & $(0.8 e-3)$ & $(0.7 e-3)$ & $(0.4 \mathrm{e}-3)$ & $(0.8 e-3)$ & $(0.3 e-3)$ & $(0.2 \mathrm{e}-3)$ & $(0.5 e-3)$ \\
\hline \multirow{2}{*}{ Male } & 0.14 & $0.11 * * *$ & 0.19 & $0.14^{* *}$ & $0.20 * * *$ & $0.27 * * *$ & $0.22 * * *$ & $0.17 * * *$ & $0.16^{* *}$ \\
\hline & $(0.15)$ & $(0.04)$ & $(0.14)$ & $(0.07)$ & $(0.04)$ & $(0.06)$ & $(0.04)$ & $(0.03)$ & $(0.08)$ \\
\hline \multicolumn{10}{|l|}{ Ownership } \\
\hline \multirow[t]{2}{*}{ SOES } & $0.33 *$ & $0.39 * * *$ & $0.51 * *$ & -0.03 & -0.08 & $-0.24 * *$ & 0.02 & -0.01 & 0.11 \\
\hline & $(0.20)$ & $(0.06)$ & $(0.21)$ & $(0.13)$ & $(0.07)$ & $(0.12)$ & $(0.07)$ & $(0.05)$ & $(0.13)$ \\
\hline \multirow[t]{2}{*}{ UCEs } & $0.55^{* * *}$ & $0.20 * * *$ & 0.01 & 0.21 & -0.03 & $-0.23 *$ & 0.11 & $0.16^{* *}$ & 0.04 \\
\hline & $(0.18)$ & $(0.05)$ & $(0.18)$ & $(0.13)$ & $(0.08)$ & $(0.13)$ & $(0.09)$ & $(0.06)$ & $(0.18)$ \\
\hline \multirow[t]{2}{*}{$J V s$} & $0.35 * *$ & $0.15^{* * *}$ & 0.14 & $0.32 * *$ & $0.22 * *$ & 0.02 & $0.11 *$ & $0.07^{*}$ & 0.04 \\
\hline & $(0.19)$ & $(0.05)$ & $(0.19)$ & $(0.17)$ & $(0.10)$ & $(0.18)$ & $(0.07)$ & $(0.04)$ & $(0.12)$ \\
\hline \multicolumn{10}{|l|}{ Occupation } \\
\hline \multirow[t]{2}{*}{ Professionals } & 0.18 & $0.16^{* *}$ & $0.41 * *$ & 0.07 & $0.15^{*}$ & $0.36^{* *}$ & $-0.15^{* * *}$ & -0.04 & 0.08 \\
\hline & $(0.24)$ & $(0.07)$ & $(0.20)$ & $(0.13)$ & $(0.08)$ & $(0.15)$ & $(0.05)$ & $(0.03)$ & $(0.09)$ \\
\hline \multirow[t]{2}{*}{ Ordinary staff } & $0.50 * * *$ & $0.13^{* *}$ & $0.33^{* *}$ & -0.03 & $0.31 * * *$ & 0.25 & 0.11 & $0.15^{* * * *}$ & 0.01 \\
\hline & $(0.18)$ & $(0.05)$ & $(0.16)$ & $(0.20)$ & $(0.11)$ & $(0.20)$ & $(0.07)$ & $(0.05)$ & $(0.15)$ \\
\hline \multirow[t]{2}{*}{ Managers/other } & $0.35 * *$ & $0.11^{* *}$ & 0.25 & 0.03 & $0.09 * *$ & $0.32 * * *$ & 0.07 & $0.34^{* * *}$ & $0.72 * * *$ \\
\hline & $(0.19)$ & $(0.06)$ & $(0.22)$ & $(0.08)$ & $(0.04)$ & $(0.08)$ & $(0.05)$ & $(0.04)$ & $(0.10)$ \\
\hline \multicolumn{10}{|l|}{ Industry } \\
\hline \multirow[t]{2}{*}{ Manufacturing } & $0.53^{* * *}$ & 0.07 & -0.16 & 0.06 & $0.16^{* * *}$ & $0.17 *$ & 0.06 & $0.05^{*}$ & -0.12 \\
\hline & $(0.16)$ & $(0.05)$ & $(0.17)$ & $(0.09)$ & $(0.05)$ & $(0.10)$ & $(0.05)$ & $(0.03)$ & $(0.09)$ \\
\hline \multirow[t]{2}{*}{ Construction } & 0.15 & -0.001 & -0.18 & $0.29 * *$ & $0.38 * * *$ & $0.39 * *$ & $0.13^{* *}$ & $0.21 * * *$ & $0.27^{* *}$ \\
\hline & $(0.24)$ & $(0.07)$ & $(0.22)$ & $(0.17)$ & $(0.10)$ & $(0.18)$ & $(0.06)$ & $(0.04)$ & $(0.12)$ \\
\hline \multirow[t]{2}{*}{ ILEP/other } & 0.21 & $0.26 * * *$ & $0.44 * *$ & $4.6 \mathrm{e}-10$ & $0.14^{* *}$ & $0.43 * * *$ & $0.15^{* *}$ & $0.09^{* *}$ & -0.06 \\
\hline & $(0.20)$ & $(0.06)$ & $(0.18)$ & $(0.11)$ & $(0.06)$ & $(0.11)$ & $(0.06)$ & $(0.04)$ & $(0.13)$ \\
\hline \multicolumn{10}{|c|}{ Receiving provinces } \\
\hline \multirow[t]{2}{*}{ Beijing/Shanghai } & 0.33 & $0.36 * * *$ & -0.10 & -0.08 & -0.02 & -0.12 & 0.03 & 0.05 & $0.20 *$ \\
\hline & $(0.31)$ & $(0.11)$ & $(0.21)$ & $(0.10)$ & $(0.06)$ & $(0.12)$ & $(0.06)$ & $(0.04)$ & $(0.12)$ \\
\hline Henan & -0.16 & $-0.24 * *$ & -0.09 & $-0.38 * * *$ & $-0.37 * * *$ & $-0.33 * * *$ & $-0.51 * * *$ & $-0.42 * * *$ & $-0.42^{* * *}$ \\
\hline & $(0.28)$ & $(0.10)$ & $(0.19)$ & $(0.09)$ & $(0.05)$ & $(0.10)$ & $(0.06)$ & $(0.04)$ & $(0.11)$ \\
\hline Jiangsu & 0.26 & $0.32 * * *$ & 0.24 & -0.08 & $-0.17 * * *$ & -0.16 & 0.01 & 0.01 & 0.02 \\
\hline & $(0.26)$ & $(0.08)$ & $(0.16)$ & $(0.08)$ & $(0.05)$ & $(0.10)$ & $(0.06)$ & $(0.04)$ & $(0.11)$ \\
\hline Anhui & $-0.67 * *$ & $-0.28 * *$ & -0.35 & $-0.36 * * *$ & $-0.42 * * *$ & -0.17 & $-0.32 * * *$ & $-0.21 * * *$ & $-0.29 * * *$ \\
\hline & $(0.39)$ & $(0.14)$ & $(0.27)$ & $(0.09)$ & $(0.06)$ & $(0.11)$ & $(0.06)$ & $(0.04)$ & $(0.11)$ \\
\hline Sichuan & 0.22 & -0.04 & -0.07 & $-0.41^{* * *}$ & $-0.46 * * *$ & $-0.55 * * *$ & $-0.29 * * *$ & $-0.33 * * *$ & $-0.25^{* *}$ \\
\hline & $(0.31)$ & $(0.11)$ & $(0.22)$ & $(0.08)$ & $(0.05)$ & $(0.10)$ & $(0.06)$ & $(0.04)$ & $(0.11)$ \\
\hline Constant & $-2.45 * * *$ & $-0.56 * * *$ & $0.65 * *$ & $-0.31 * *$ & $0.29 * * *$ & $0.56^{* * *}$ & $0.74 * * *$ & $1.00^{* * *}$ & $1.61^{* * *}$ \\
\hline & $(0.34)$ & $(0.07)$ & $(0.26)$ & $(0.12)$ & $(0.08)$ & $(0.17)$ & $(0.11)$ & $(0.07)$ & $(0.18)$ \\
\hline Pseudo $\mathrm{R}^{\wedge} 2$ & 0.15 & 0.14 & 0.11 & 0.13 & 0.14 & 0.16 & 0.12 & 0.10 & 0.09 \\
\hline Observations & 577 & 577 & 577 & 1,460 & 1,460 & 1,460 & 2,431 & 2,431 & 2,431 \\
\hline
\end{tabular}




\section{Appendix}

Table A1. Working times between 1995 and 2008 for rural migrant workers

\begin{tabular}{|c|c|c|c|c|c|c|c|c|c|c|}
\hline & \multicolumn{4}{|c|}{1995} & \multicolumn{4}{|c|}{2002} & \multirow{2}{*}{\multicolumn{2}{|c|}{$\begin{array}{c}2008 \\
\begin{array}{c}\text { Hours per } \\
\text { week }\end{array}\end{array}$}} \\
\hline & \multicolumn{2}{|c|}{$\begin{array}{c}\text { Days per } \\
\text { week }\end{array}$} & \multicolumn{2}{|c|}{$\begin{array}{c}\text { Hours per } \\
\text { day }\end{array}$} & \multicolumn{2}{|c|}{$\begin{array}{c}\text { Days per } \\
\text { week }\end{array}$} & \multicolumn{2}{|c|}{$\begin{array}{c}\text { Hours per } \\
\text { day }\end{array}$} & & \\
\hline & Mean & SD & Mean & SD & Mean & $\mathrm{SD}$ & Mean & SD & Mean & $\mathrm{SD}$ \\
\hline \multicolumn{11}{|l|}{ Education } \\
\hline Preliminary and below & 6.2 & 0.8 & 9.1 & 1.5 & 6.8 & 0.7 & 10.5 & 2.5 & 68.5 & 19.1 \\
\hline Junior & 6.2 & 0.8 & 8.9 & 1.4 & 6.7 & 0.8 & 10.4 & 2.5 & 63.0 & 17.3 \\
\hline Senior & 6.0 & 0.8 & 8.7 & 1.5 & 6.6 & 0.8 & 9.9 & 2.3 & 59.3 & 16.3 \\
\hline College and above & 6.0 & 0.6 & 8.3 & 1.3 & 6.2 & 0.8 & 9.4 & 2.0 & 55.8 & 16.1 \\
\hline \multicolumn{11}{|l|}{ By ownership } \\
\hline SOES & 5.8 & 0.7 & 8 & 1.2 & 6.4 & 0.9 & 9.3 & 2.8 & 56.5 & 15.5 \\
\hline UCES & 6.1 & 0.9 & 8.5 & 1.4 & 6.5 & 0.7 & 9.3 & 2.0 & 58.2 & 15.9 \\
\hline Private/FIEs & 6.3 & 0.7 & 9.2 & 1.4 & 6.8 & 0.7 & 10.5 & 2.3 & 65.7 & 17.9 \\
\hline$J V s$ & 6.0 & 0.8 & 8.9 & 1.5 & 6.1 & 0.8 & 9.0 & 1.9 & 53.3 & 13.8 \\
\hline \multicolumn{11}{|l|}{ By occupation } \\
\hline Professional/Skilled workers & 6.0 & 0.6 & 8.0 & 0.9 & 6.2 & 0.9 & 9.3 & 1.9 & 50.0 & 12.0 \\
\hline Ordinary staff & 6.0 & 0.6 & 8.0 & 0.9 & 6.4 & 0.9 & 9.1 & 2.4 & 53.9 & 14.0 \\
\hline Unskilled workers & 6.1 & 0.7 & 8.9 & 1.6 & 6.6 & 0.8 & 9.9 & 2.5 & 62.9 & 16.7 \\
\hline Managers/other & 6.2 & 0.9 & 8.9 & 1.4 & 6.5 & 0.9 & 9.9 & 2.9 & 62.1 & 17.1 \\
\hline \multicolumn{11}{|l|}{ By industry } \\
\hline Manufacturing & 5.9 & 0.7 & 8.7 & 1.3 & 6.5 & 0.9 & 9.4 & 2.1 & 55.7 & 15.1 \\
\hline Construction & 6.3 & 0.8 & 9.0 & 1.2 & 6.3 & 1.1 & 9.3 & 1.7 & 62.7 & 12.9 \\
\hline Social services & 6.3 & 0.8 & 9.1 & 1.6 & 6.8 & 0.7 & 10.8 & 2.3 & 67.9 & 18.8 \\
\hline ILEP/other & 6.4 & 0.9 & 9.0 & 1.5 & 6.6 & 0.8 & 10.0 & 2.7 & 50.3 & 14.8 \\
\hline Number of Obs. & \multicolumn{4}{|c|}{672} & \multicolumn{4}{|c|}{1,418} & \multicolumn{2}{|c|}{2,598} \\
\hline
\end{tabular}

Table A2. Category of industry

\begin{tabular}{|c|c|c|c|}
\hline Industries & \multicolumn{3}{|c|}{ Employment percentage (\%) } \\
\hline & 1995 & 2002 & 2008 \\
\hline \multicolumn{4}{|l|}{ Industries with low employment percentage (ILEP) } \\
\hline Mineral & & 0.23 & 0.01 \\
\hline Geological prospecting, irrigation administration & 0.07 & 0.03 & 0.35 \\
\hline Electricity, gas and water production and supply & - & 0.68 & 0.11 \\
\hline Finance and insurance & 0.27 & 0.29 & 0.22 \\
\hline Real estate & 0.07 & 0.70 & 2.90 \\
\hline Scientific research and professional services & 0.14 & 0.38 & 3.09 \\
\hline Health, sports and social welfare & 0.34 & 1.14 & 1.94 \\
\hline Education, culture, arts, broadcast, movies, television & 0.27 & 1.35 & 2.00 \\
\hline Government agents, party organizations and social groups & 0.21 & 1.17 & 0.18 \\
\hline Materials supply and marketing, warehousing & 0.75 & - & - \\
\hline public utilities & 0.14 & - & 3.66 \\
\hline Transportation, storage, post office and communication & 2.88 & 2.67 & 3.00 \\
\hline \multicolumn{4}{|l|}{ Other industries } \\
\hline Manufacturing & - & 9.80 & 18.69 \\
\hline Industry & 29.34 & - & - \\
\hline Construction & 24.40 & 4.73 & 10.14 \\
\hline Wholesale, retail and food services & 9.93 & 47.02 & 46.57 \\
\hline Social service & 3.56 & 21.34 & 9.39 \\
\hline other & 27.62 & 8.45 & 0.74 \\
\hline Observations & 1,459 & 3,407 & 7,078 \\
\hline
\end{tabular}


Table A3. Economic growth rate in China from 1978 to 2010

\begin{tabular}{ccccc}
\hline Year & GDP (Billion yuan) & GDP growth rate (\%) & Inflation rate (\%) & GDP/per capita (Yuan) \\
\hline 1978 & 364.5 & 11.7 & 0.7 & 381 \\
1979 & 406.3 & 7.6 & 2.0 & 419 \\
1980 & 454.6 & 7.8 & 6.0 & 463 \\
1981 & 489.2 & 5.3 & 2.4 & 492 \\
1982 & 532.3 & 9.0 & 1.9 & 528 \\
1983 & 596.3 & 10.9 & 1.5 & 583 \\
1984 & 720.8 & 15.2 & 2.8 & 659 \\
1985 & 901.6 & 13.5 & 9.3 & 858 \\
1986 & 1027.5 & 8.9 & 6.5 & 963 \\
1987 & 1205.9 & 11.6 & 7.3 & 1112 \\
1988 & 1504.3 & 11.3 & 18.8 & 1366 \\
1989 & 1699.2 & 4.1 & 18.0 & 1644 \\
1990 & 1866.8 & 3.8 & 3.1 & 1893 \\
1991 & 2178.2 & 9.2 & 3.4 & 2311 \\
1992 & 2692.4 & 14.2 & 6.4 & 2998 \\
1993 & 3533.4 & 14.0 & 14.7 & 4044 \\
1994 & 4819.8 & 13.1 & 24.1 & 5046 \\
1995 & 6079.4 & 10.9 & 17.1 & 6846 \\
1996 & 7117.7 & 10.0 & 8.3 & 6796 \\
1997 & 7897.3 & 9.3 & 2.8 & 7159 \\
1998 & 8440.2 & 7.8 & -0.8 & 7858 \\
1999 & 8967.7 & 7.6 & -1.4 & 8622 \\
2000 & 9921.5 & 8.4 & 0.4 & 9398 \\
2001 & 10965.5 & 8.3 & 0.7 & 10542 \\
2002 & 12033.3 & 9.1 & -0.8 & 12336 \\
2003 & 13582.3 & 10.0 & 1.2 & 14040 \\
2004 & 15987.8 & 10.1 & 3.9 & 16024 \\
2005 & 18308.5 & 10.2 & 1.8 & 18868 \\
2006 & 21192.4 & 11.6 & 1.5 & 23128 \\
2007 & 24953.1 & 11.9 & 4.8 & 25109 \\
2008 & 30067.0 & 9.0 & 5.9 & \\
2009 & 34090.3 & 9.2 & -0.7 &
\end{tabular}

